\title{
SISTEM PENDUKUNG KEPUTUSAN KLINIS UNTUK MEMPREDIKSI KEJADIAN ASFIKSIA NEONATORUM
}

\author{
Efi Laila Latifah, Sri Kusumadewi, \& Yasmini Fitriyati \\ Universitas Islam Indonesia \\ e-mail: efilaila92@yahoo.com
}

\begin{abstract}
Asphyxia neonatorum is a newborn emergency in the form of respiratory depression that continues, causing various complication even death. According to RISKESDAS Indonesia 2007, 78,5\% of infant mortality occur in an early neonatal with the greatest cause due to asphyxia neonatorum. Therefore, a tool for early detection of potential of asphyxia neonatorum in each pregnancies is needed. That early identification can be done by implementing Rule Based Reasoning with Forward Chaining method followed by Case Based Reasoning in a system. The system developed in this research provide the output in APGAR score prediction. System testing in this research indicate the acceptance of system both functionality and usability are in 'Very Good' category with an average acceptance score of $92,73 \%$.
\end{abstract}

Keywords: Asphyxia neonatorum, APGAR Score, Rule Based Reasoning, Case Based Reasoning

\begin{abstract}
ABSTRAK
Asfiksia neonatorum merupakan kegawatdaruratan bayi baru lahir berupa depresi pernafasan yang berlanjut sehingga menimbulkan berbagai komplikasi bahkan mengakibatkan kematian. Menurut RISKESDAS Indonesia 2007, 78,5\% kematian bayi merupakan kematian neonatal dini dengan penyebab terbesar karena asfiksia neonatorum. Oleh karena itu diperlukan suatu alat untuk mendeteksi dini potensi atau resiko kejadian asfiksia neonatorum pada setiap kehamilan. Identifikasi dini tersebut dapat dilakukan dengan mengaplikasikan Rule Based Reasoning dengan metode Forward Chaining yang dilanjutkan dengan Case Based Reasoning dalam sebuah sistem. Sistem yang dikembangkan dalam penelitian ini menghasilkan output berupa prediksi skor APGAR neonatus. Hasil pengujian sistem dalam penelitian ini menunjukkan bahwa penerimaan sistem baik fungsional maupun usabilitas berada dalam kategori sangat baik dengan nilai rata-rata sebesar $92,73 \%$.
\end{abstract}

Kata kunci: Asfiksia Neonatorum, Skor APGAR, Rule Based Reasoning, Case Based Reasoning

\section{PENDAHULUAN}

Riset Kesehatan Dasar (RISKESDAS) Indonesia tahun 2007 meunjukkan bahwa 78.5\% jumlah kematian bayi merupakan kematian bayi neonatal dini (0-6 hari) dengan proporsi terbesar disebabkan karena respiratory disorders (asfiksia neonatorum), prematuritas, dan sepsis. Sedangkan berdasarkan data World Health Organization (WHO), pada tahun 2013, terdapat 2,8 juta kasus kematian neonatus, dengan tingkat mortalitas 20 kasus setiap 1000 bayi lahir hidup (World Health Statistic, 2015). Pada tahun 2015, diperkirakan terdapat 5,9 juta kasus kematian anak di bawah 5 tahun, di mana $45 \%$ dari jumlah tersebut terjadi pada neonatus. Tingkat mortalitas neonatus diperkirakan sebesar 19 kasus dari 1000 bayi lahir hidup. Penyebab tertinggi mortalitas neonatus pada 2015 adalah prematuritas, komplikasi pada saat persalinan (asfiksia neonatorum), dan sepsis (World Health Statistic, 2016).

Asfiksia neonatorum merupakan kegawatdaruratan bayi baru lahir berupa depresi pernafasan yang berlanjut sehingga menimbulkan berbagai komplikasi. Pada kelahiran dengan asfiksia, bayi harus segera diberikan resusitasi. Asfiksia neonatorum 
ditunjukkan dengan skor APGAR (Appearance, Pulse, Grimace, Activity, Respiration). Skor APGAR merupakan metode yang digunakan untuk menilai keadaan bayi sesaat setelah lahir (Prawirohardjo, 2002). Tenaga medis memberikan nilai pada masingmasing aspek dengan nilai 0,1 , atau 2. Jumlah nilai dari 5 aspek tersebut kemudian dikategorikan menjadi bayi normal dengan nilai total $>7$, asfiksia ringan dengan nilai total $4-7$, dan asfiksia berat dengan nilai total $<$ 4.Penanganan asfiksia sangat penting karena jika tidak tertangani secara cepat dan baik, akan menyebabkan kematian, atau bayi dapat bertahan hidup tetapi mengalami cacat karena kekurangan suplai oksigen ke otak.

Kejadian asfiksia neonatorum berhubungan dengan faktor-faktor selama kehamilan, ketika persalinan, atau segera setelah bayi lahir. Gangguan menahun juga dapat berpengaruh terhadap janin dalam terganggunya oksigenasi serta kurangnya pemberian zat-zat makanan berhubungan dengan gangguan fungsi plasenta. Gangguan menahun dalam kehamilan dapat berupa gizi ibu yang buruk, penyakit menahun seperti anemia, hipertensi, penyakit jantung, dan lainlain.

Faktor-faktor terjadinya asfiksia yang timbul dalam persalinan bersifat lebih mendadak dan hampir selalu mengakibatkan hipoksia janin dan berakhir dengan asfiksia bayi. Namun, keadaan-keadaan ini dapat dikenali dengan memperhatikan keadaan beberapa saat sebelum persalinan, sehingga dapat dilakukan persiapan yang sempurna pada saat bayi lahir(Wiknjosastro, 2005). Beberapa penelitian juga telah meneliti berbagai faktor resiko yang berhubungan dengan kejadian asfiksia neonatorum, di antaranya penelitian yang dilakukan oleh Gilang (2012) yang menyimpulkan bahwa faktor yang berpengaruh pada kejadian asfiksia neonatorum secara berurutan yaitu berat badan lahir bayi, perdarahan antepartum, KPD, posisi bayi sungsang yang dilahirkan pervaginam, posisi bayi sungsang yang dilahirkan perabdominam, partus lama, dan usia ibu.

Penelitian lain yang dilakukan oleh Utomo (2011) menyimpulkan bahwa faktor yang berpengaruh terhadap kejadian asfiksia neonatorum antara lain perdarahan antepartum, preeklampsia, prematuritas, post maturitas, berat lahir rendah, dan bedah sesar. Sejalan dengan penelitian tersebut, adalah penelitian yang dilakukan oleh Brillianningtyas (2014) yang menyimpulkan bahwa terdapat hubungan yang signifikan antara usia kehamilan lewat waktu dan usia kehamilan prematur dengan kejadian asfiksia neonatorum. Penelitian lain yang dilakukan oleh Herawati (2013) menyimpulkan bahwa solusio plasenta, plasenta previa, kehamilan gemeli, dan gangguan tali pusat memiliki hubungan dengan kejadian asfiksia neonatorum.

Kejadian asfiksia sendiri terkadang tidak dapat diperkirakan oleh tenaga kesehatan. Namun, masih dimungkinkan dilakukan identifikasi awal resiko terjadinya asfiksia neonatorum dengan mengetahui faktor-faktor resiko asfiksia neonatorum tersebut. Karena pentingnya identifikasi dini akan resiko atau potensi kejadian asfiksia, diperlukan suatu sistem yang dapat memprediksi potensi kejadian asfiksia pada proses persalinan yang akan dilakukan.

Dalam memprediksi, sistem menggunakan dua metode yang diaplikasikan secara berurutan, yaitu rule based reasoning kemudian case based reasoning. Rule based reasoning $(\mathrm{RBR})$ merupakan salah satu metode yang digunakan untuk menyelesaikan suatu permasalahan di mana basis pengetahuan yang digunakan direpresentasikan dalam suatu aturan-aturan (rule) (Turban, 2005). Sedangkan Case based reasoning (CBR) adalah suatu pendekatan untuk menyelesaikan suatu permasalahan (problem solving) berdasarkan solusi dari permasalahan sebelumnya (Aamodt dan Plaza, 1994).

Dengan sistem tersebut diharapkan tenaga medis dapat segera mengidentifikasi ibu hamil dengan resiko asfiksia neonatorum 
dan dapat melakukan tindakan untuk mengantisipasi kemungkinan terjadinya asfiksia neonatorum tersebut.

\section{METODE}

Penelitian ini dilakukan dalam beberapa tahapan yaitu wawancara dan studi literatur, pengambilan data, analisis model RBR, analisis model CBR, analisis sistem, perancangan sistem, implementasi sistem, dan pengujian sistem. Tahapan awal dalam penelitian ini yaitu wawancara yang dilakukan dengan bidan dan dokter spesialis kandungan. Wawancara dilakukan untuk mengetahui pengetahuan dasar mengenai asfiksia neonatorum dan fakta-fakta yang terjadi di lapangan berkaitan dengan kejadian asfiksia neonatorum. Dasar-dasar pengetahuan kemudian dikembangkan dengan melakukan studi literatur mengenai asfiksia neonatorum dan faktor risikonya, serta mendapatkan referensi dalam menentukan pendekatan yang dapat diimplementasikan dalam suatu sistem untuk memprediksi kejadian asfiksia neonatorum yang lebih spesifik ditunjukkan oleh skor APGAR.

Tahapan selanjutnya adalah pengambilan data berkaitan dengan kejadian asfiksia neonatorum. Data yang digunakan sebagai basis kasus pada penelitian ini adalah 106 data bayi dan ibu melahirkan yang diperoleh dari Instalasi Rekam Medik RSKIA Sadewa Yogyakarta. Data rekam medik yang digunakan memiliki rentang waktu kelahiran bayi dengan asfiksia neonatorum pada Januari 2016 sampai dengan Desember 2016. Data yang diperoleh berkaitan dengan faktor risiko asfiksia neonatorum terdiri atas data kualitatif seperti penyulit persalinan (presentasi janin, KPD, kelainan plasenta, preeklampsia/eklampsia, lilitan tali pusat, dll), riwayat penyakit ibu, riwayat ginekologi, konsumsi alkohol/obat-obatan, cacat bawaan janin, status ANC dan kejadian asfiksia bayi baru lahir, serta data kuantitatif seperti usia ibu, usia kehamilan, jumlah janin, denyut jantung janin (DJJ), perkiraan berat bayi, kadar hemoglobin ibu dan tekanan darah ibu.

Data DJJ direpresentasikan menjadi aturan dalam sistem sebagai pendekatan RBR, sedangkan data selain DJJ menjadi atribut dalam CBR. Masing-masing atribut memiliki bobot sesuai dengan hasil penelitian sebelumnya dan verifikasi dari dokter spesialis kandungan.

Secara garis besar, sistem akan menerima input berupa data kontrol ibu hamil kemudian memproses data DJJ terlebih dahulu dalam RBR. Kasus dengan nilai DJJ tidak normal dikategorikan menjadi kasus asfiksia neonatorum. Sedangkan kasus dengan nilai DJJ normal akan kemudian diproses dengan CBR dengan melakukan proses retrieve basis kasus dengan melakukan perhitungan nilai similarity kasus baru dengan masing-masing basis kasus dengan rumus sebagai berikut :

$$
\operatorname{similarity}(T, S)=\frac{\sum_{i=1}^{n} f\left(T_{i}, S_{i}\right) \times w_{i}}{w_{i}} \ldots \ldots
$$

Keterangan:

$\mathrm{T}$ : kasus baru

$\mathrm{S}$ : basis kasus

$\mathrm{n}$ : jumlah atribut dalam setiap kasus

$\mathrm{i}$ : atribut individu (1 sampai $\mathrm{n}$ )

$\mathrm{f}$ : fungsi similarity atribut $\mathrm{t}$ antara kasus $\mathrm{T}$ dengan basis kasus $\mathrm{S}$

$\mathrm{w}$ : bobot atribut $\mathrm{t}$

dengan

$$
f\left(T_{i}, S_{i}\right)= \begin{cases}1, & T_{i}=S_{i} \\ 0, & T_{i} \neq S_{i}\end{cases}
$$

Jika ditemukan kasus yang memenuhi nilai threshold yang telah ditentukan oleh dokter spesialis kandungan, maka solusi dari kasus tersebut digunakan sebagai solusi dari kasus baru (reuse). Solusi tersebut dapat diperbaiki (revise) terlebih dahulu sebelum kemudian dilakukan verifikasi oleh dokter spesialis kandungan untuk menjadi basis kasus dalam sistem (retain). Sebagai output dari sistem yaitu skor APGAR. 
Pengujian sistem kemudian dilakukan setelah sistem dikembangkan. Pengujian sistem difokuskan pada functionality dan usabilitysystem. Metode yang digunakan untuk melakukan pengujian adalah dengan pengisian angket yang dilakukan oleh calon pengguna sistem yaitu bidan dan dokter spesialis kandungan.

\section{HASIL}

Sistem yang dikembangkan dalam penelitian ini digunakan oleh tiga jenis pengguna sistem dengan hak akses yang berbeda yaitu: (1) Administrator sistem, dengan hak akses dalam manajemen pengguna sistem, manajemen kategorisasi data masukan, manajemen data ibu dan manajemen data kontrol kehamilan; (2) Bidan, dengan hak akses manajemen data ibu dan data kontrol kehamilan ibu; dan (3) Dokter spesialis kandungan, dengan hak akses manajemen data kontrol kehamilan ibu, verifikasi prediksi dan manajemen informasi kejadian asfiksia neonatorum, serta verifikasi kasus baru dan hasil prediksi yang akan digunakan sebagai basis kasus. Gambar 1 menunjukkan gambaran umum sistem.

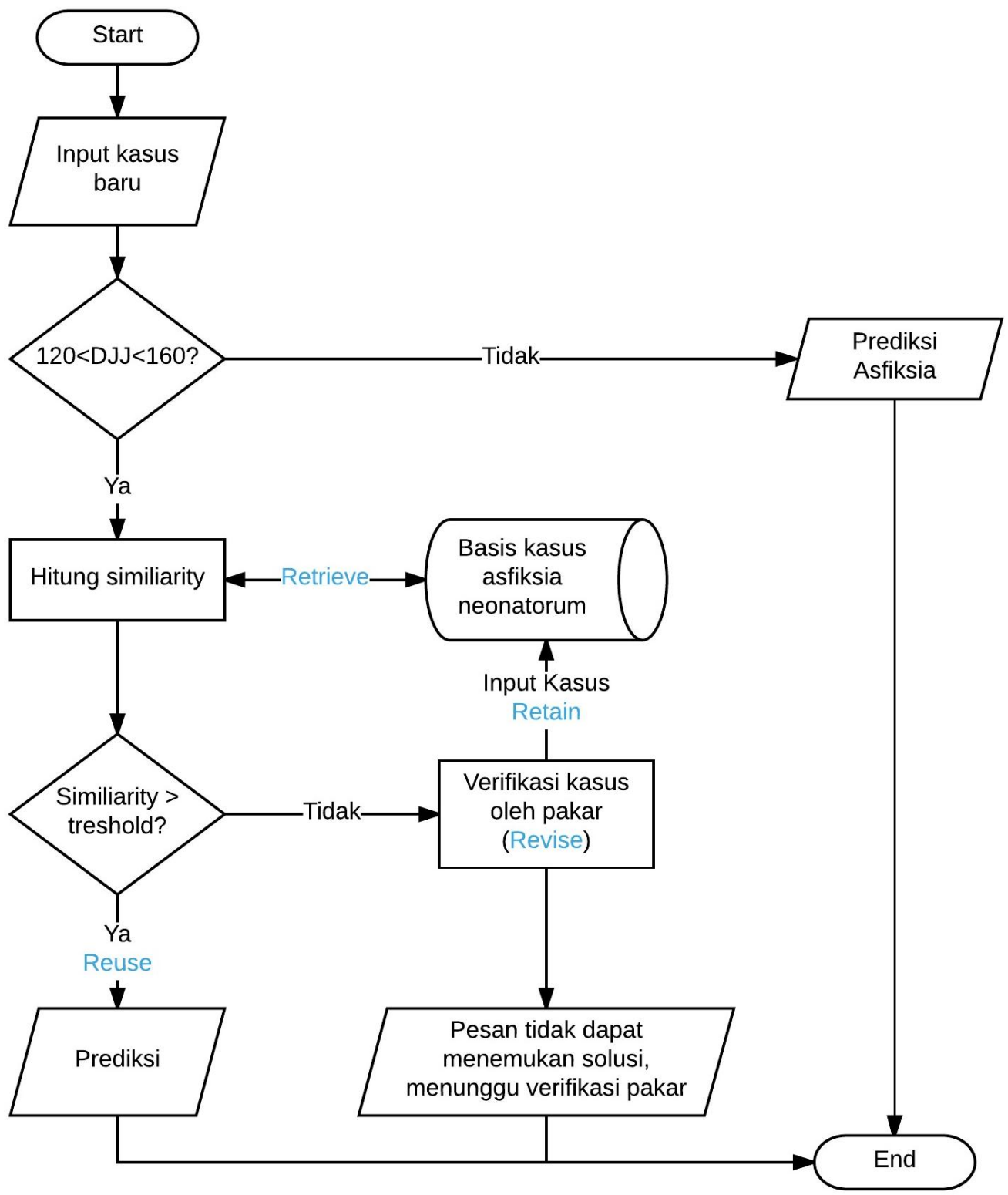

Gambar 1. Gambaran Umum Alur Sistem 
Sistem memiliki aturan untuk Rule Based Reasoning yaitu: IF $120<$ DJJ $<140$ THEN CBR ELSE Asfiksia. Untuk Case Based Reasoning, sistem menggunakan atribut-atribut dalam menghitung similarity kasus yaitu: (1) Usia ibu; (2) Usia kehamilan; (3) Tekanan darah ibu; (4) Presentasi Janin; (5) Kondisi air ketuban; (6) Kelainan Plasenta; (7) Preeklampsia/ eklampsia; (8) Lilitan Tali pusat; (9) IMT (Indeks Massa Tubuh) Ibu; (10) Riwayat Penyakit Ibu; (11) Riwayat
Obstetri dan Ginekologi; (12) Taksiran berat janin; (13) Konsumsi alkohol/ obat-obatan; (14) Cacat bawaan janin; (15) Kadar Hemoglobin; (16) Jumlah Janin; dan (17) Status Antenatal Care.

Proses dan alur data dalam sistem secara keseluruhan serta entitas sebagai pengguna sistem dengan masing-masing hak atas data yang menjadi masukan maupun informasi sebagai keluaran sistem ditunjukkan dengan diagram konteks pada Gambar 2.

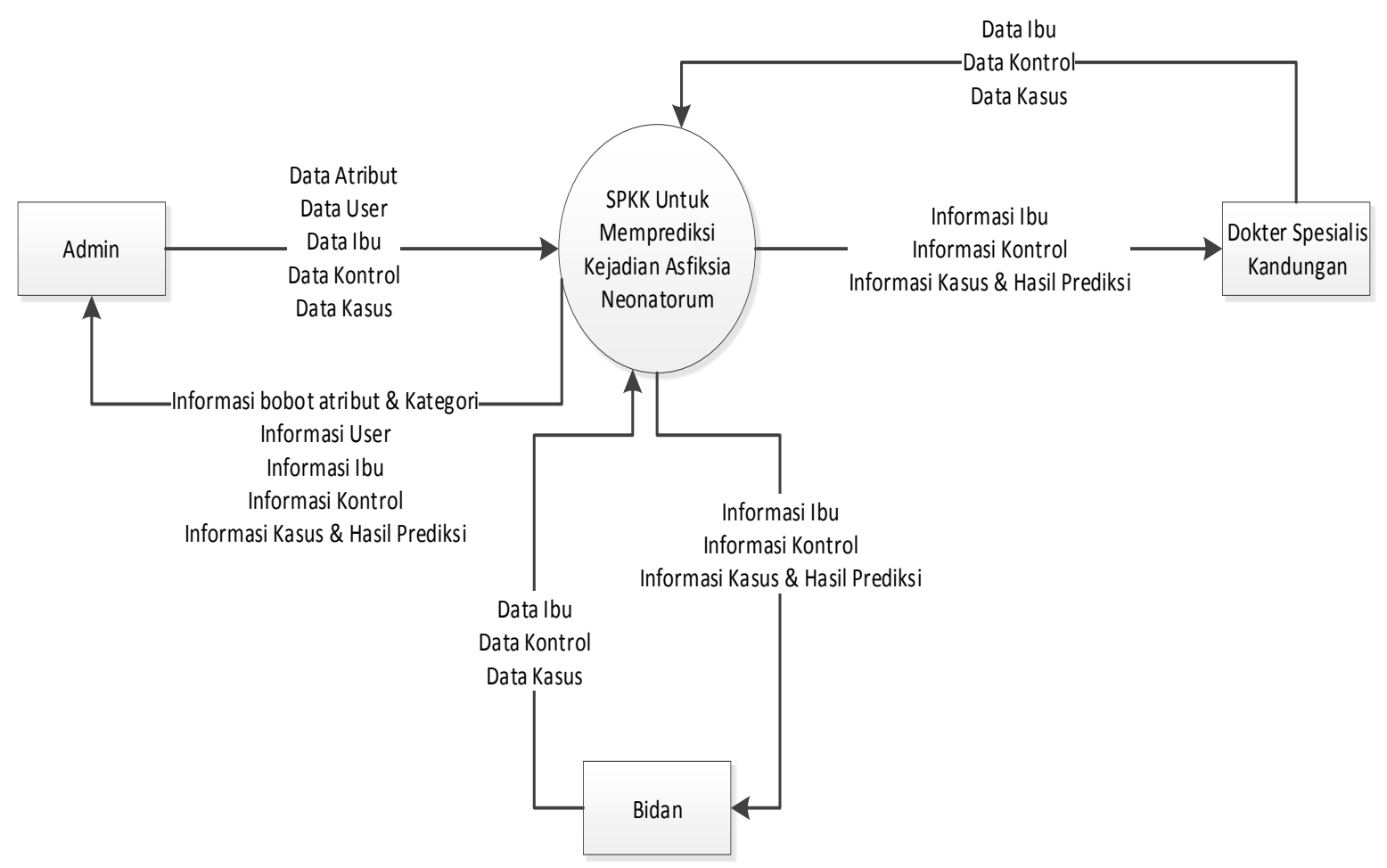

Gambar 2. Diagram Konteks

Dalam pengembangan sistem, data yang dibutuhkan memiliki relasi/hubungan dengan data lain. Gambar 3 merupakan diagram relasi antar tabel yang menunjukkan hubungan antar tabel dalam sistem yang dibangun pada penelitian ini. 


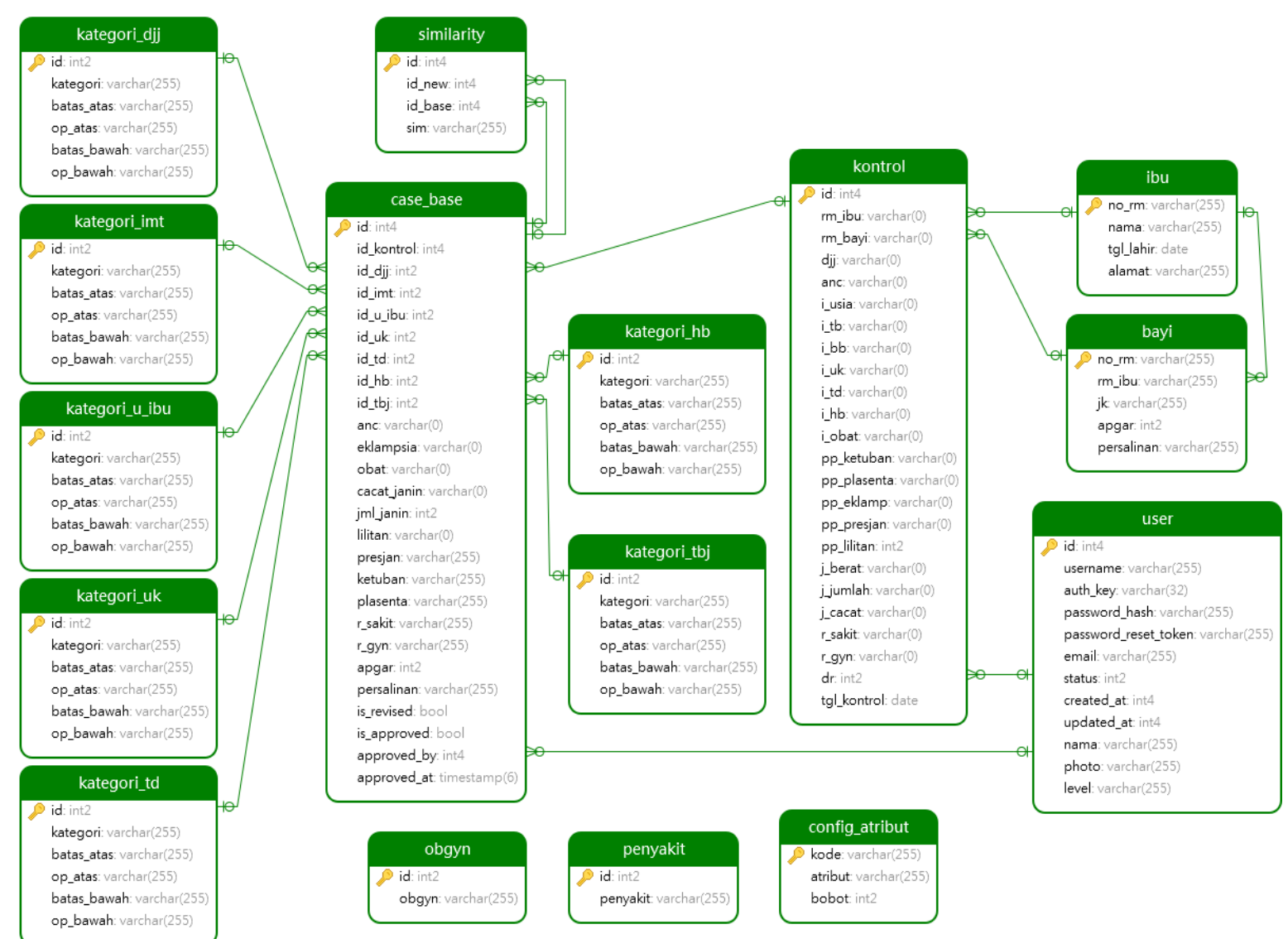

Gambar 3. Diagram Relasi Antar Tabel

Dalam penelitian ini, sistem seperti pada Gambar 4 sebagai halaman awal diimplementasikan dalam bentuk web-based sistem setelah user melakukan login. system. Antarmuka sistem yang dibangun

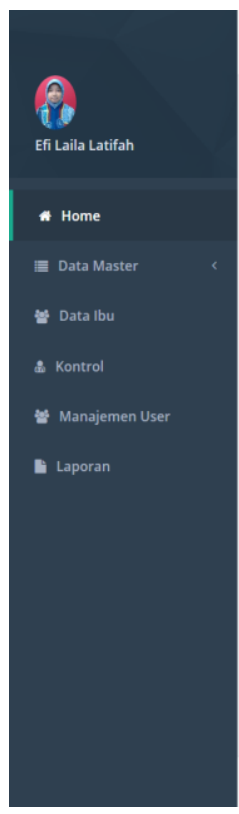

SPKK Kejadian Asfiksia Neonatorum

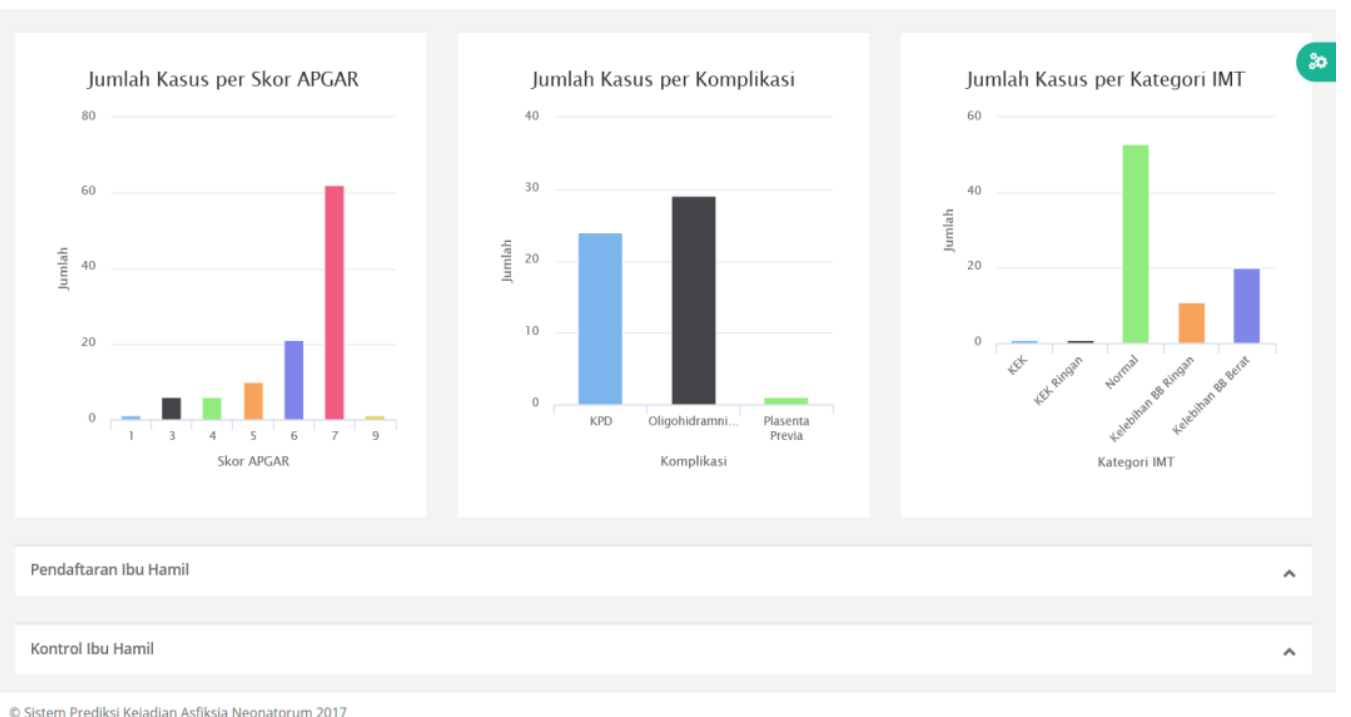

Gambar 4. Halaman Awal SPKK 
User kemudian dapat memasukkan data hasil pemeriksaan ibu hamil sesuai dengan isian-isian yang disediakan oleh sistem pada halaman input kontrol yang ditunjukkan pada Gambar 5.

\section{Kontrol Ibu Hamil}

No. RM : 110592

- $\quad$ - 07 -Nov-2017
Nama : $\mathbf{X Y}$

Janin

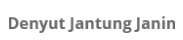

Taksiran Berat Janin - gram

Jml Janin

Presentasijanin $\bigcirc$ Kepala $\bigcirc$ Bokong $\bigcirc$ Lintang $\bigcirc$ Kaki Lainnya :

Cacat Janin

jika tidak ada Pisahkan dengan tanda koma (,)

Komplikasi

Biarkan kosong jika tidak ada Pisahkan dengan tanda koma (,)

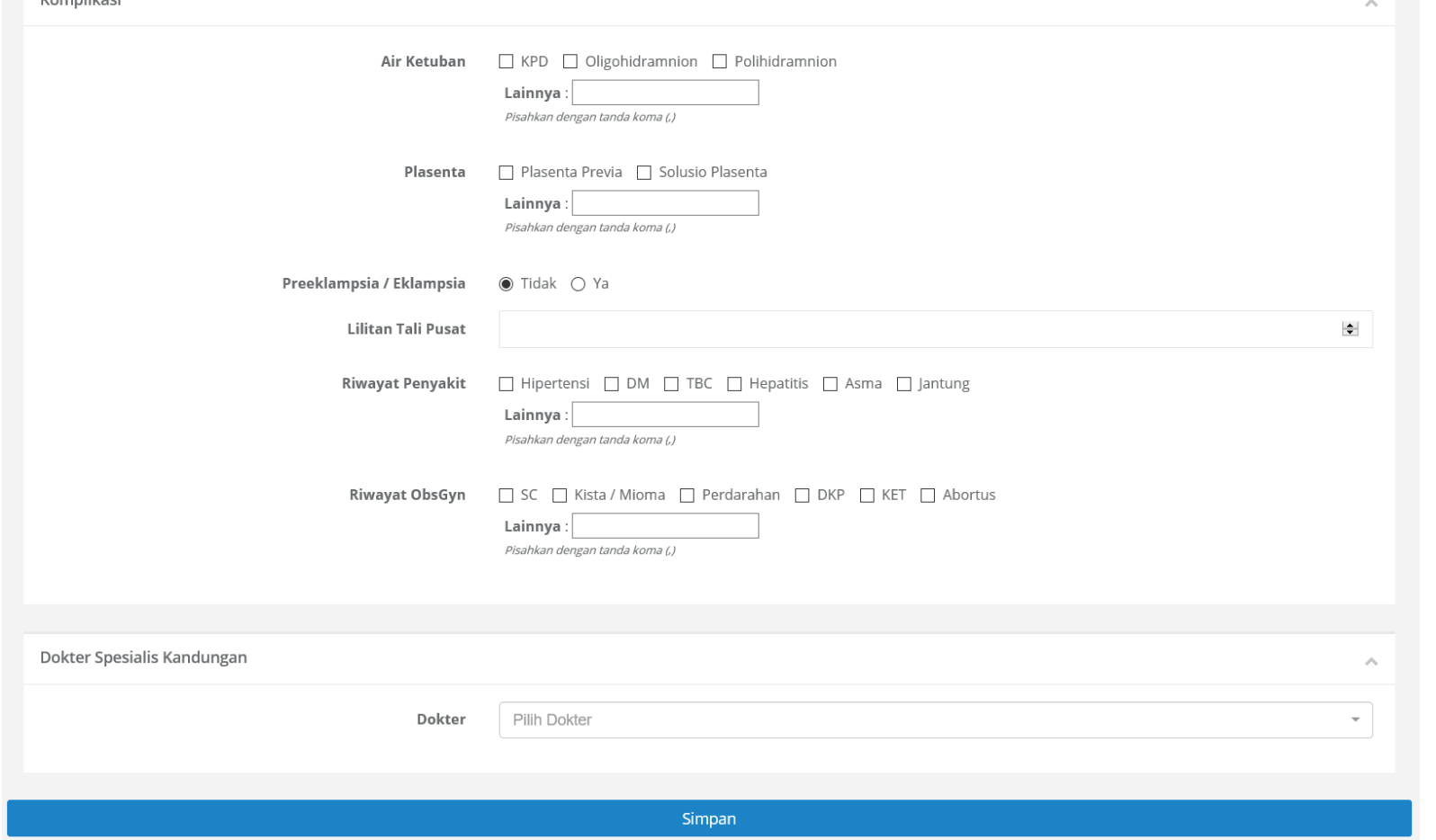

Gambar 5. Halaman Input Kontrol

Halaman detail kontrol seperti pada Gambar 6 secara otomatis akan muncul setelah user menyimpan data kontrol. Halaman ini mencakup informasi skor APGAR kejadian asfiksia hasil prediksi sistem di bagian kanan atas halaman. 


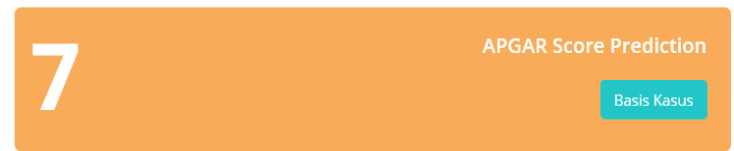

Kondisi Ibu

Usia 28 tahu

Tekanan Darah $140 / 100$

Tinggi Badan (cm) $156 \mathrm{~cm}$

Berat Badan (kg) $\quad 60 \mathrm{~kg}$

\begin{tabular}{ll} 
Air Ketuban & Oligohidramnion \\
\hline Plasenta & - \\
\hline Preeklampsia / Eklampsia & Ya \\
\hline Lilitan Tali Pusat & - \\
\hline Riwayat Penyakit & Hipertensi \\
\hline Riwayat ObsGyn & -
\end{tabular}

\section{Gambar 6. Halaman Detail Kontrol}

Berdasarkan data kontrol yang secara otomatis. Gambar 7 menunjukkan basis diinputkan, terdapat basis kasus dengan nilai similarity memenuhi threshold sistem $(85 \%)$ sehingga solusi prediksi skor APGAR tersedia kasus yang memenuhi threshold pada kasus yang bersesuaian. Halaman ini juga berfungsi untuk melakukan revise solusi sistem.

\begin{tabular}{|c|c|c|c|c|c|}
\hline No & No. Kasus & TD & Similarity & APGAR & Aksi \\
\hline 1 & 75 & $140 / 90$ & 0.91379310344828 & 7 & 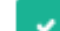 \\
\hline
\end{tabular}

Gambar 7. Basis Kasus Memenuhi Threshold

Proses revise hasil prediksi skor APGAR dilakukan oleh dokter spesialis kandungan dengan mengubah nilai skor
APGAR hasil prediksi seperti ditunjukkan pada Gambar 8. 


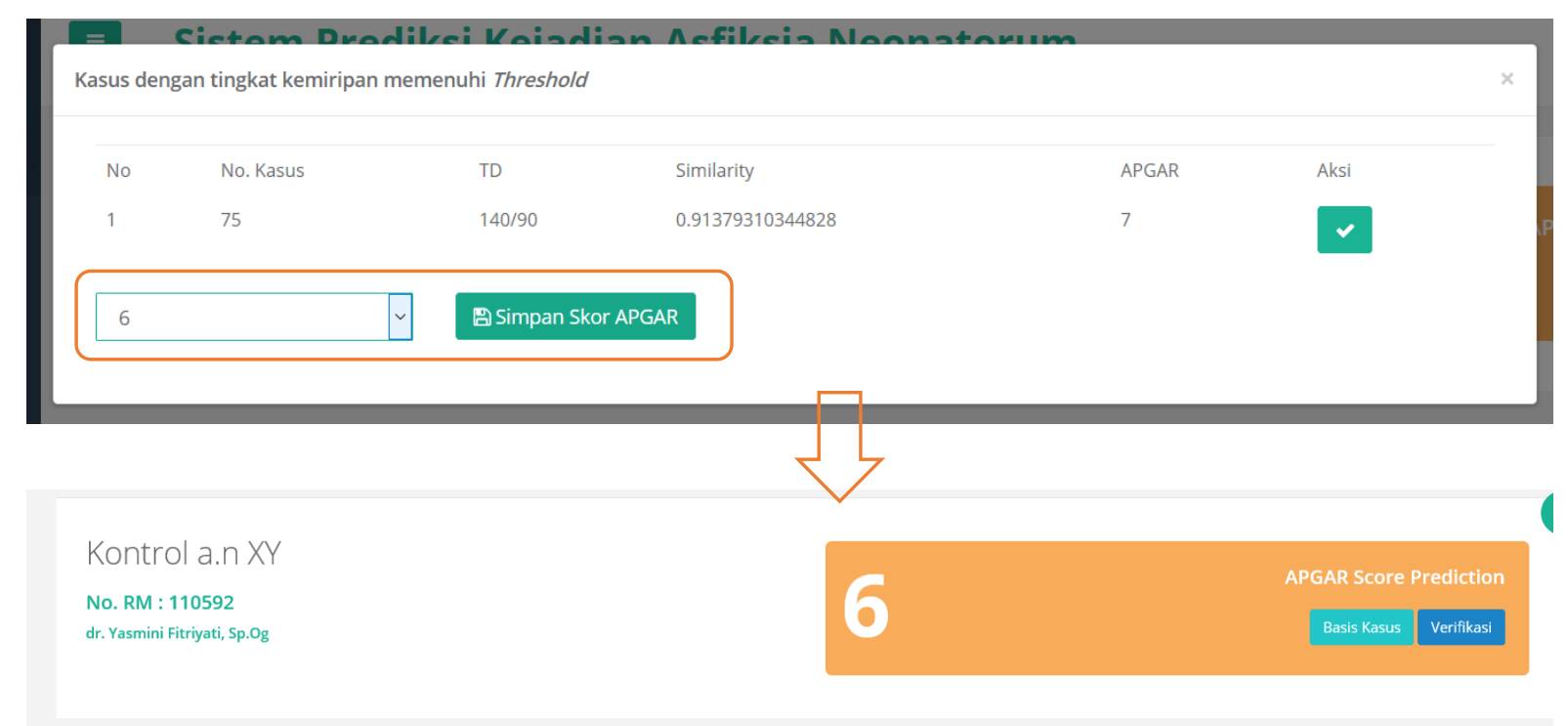

\section{Gambar 8. Proses Revise}

Proses selanjutnya yaitu verifikasi kasus untuk memasukkan kasus baru ke dalam basis kasus dan menjadi pengetahuan untuk sistem.
Proses ini dilakukan oleh dokter spesialis kandungan. Proses retain ditunjukkan pada Gambar 9.

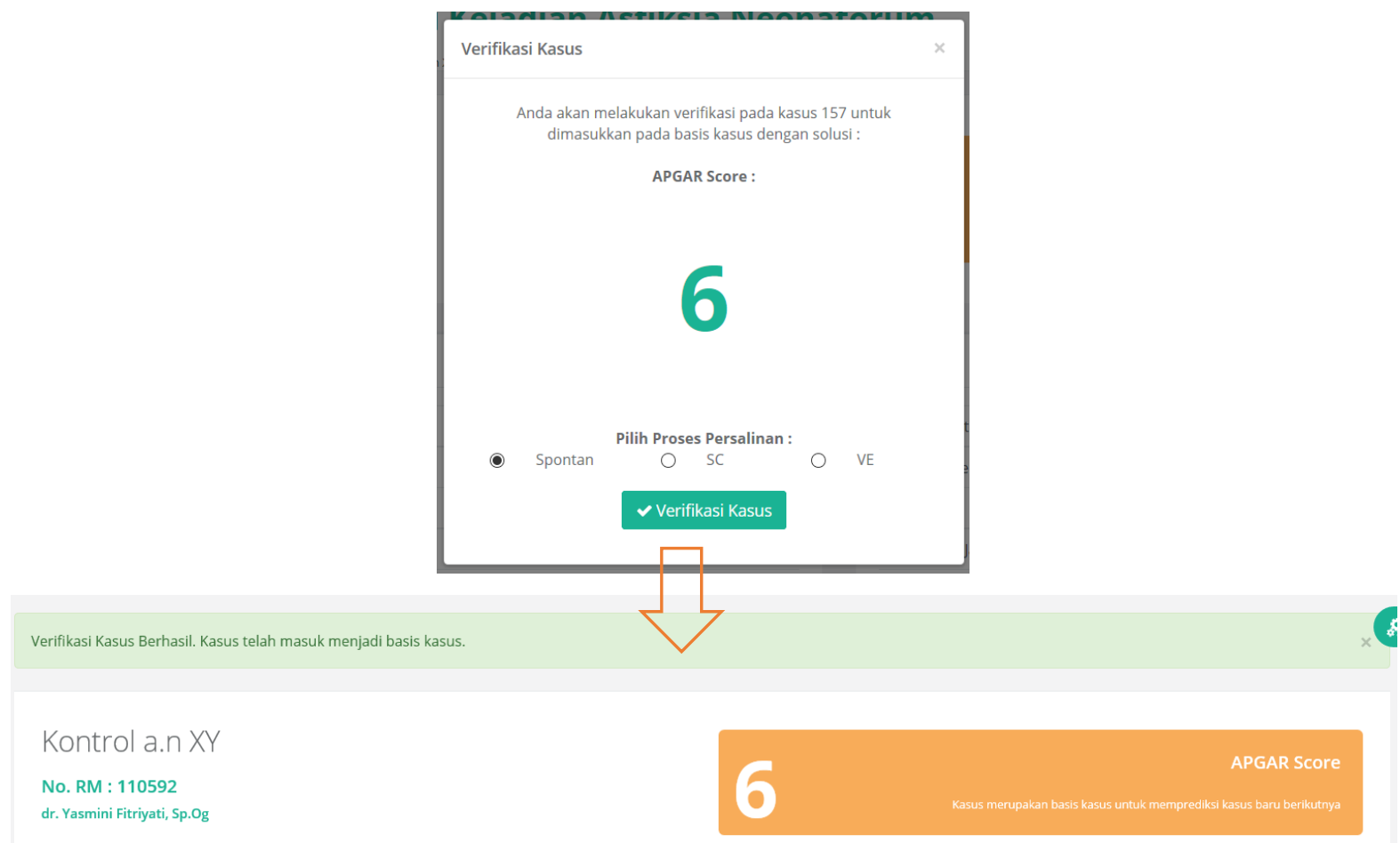

Gambar 9. Proses Retain 
Pengujian sistem dilakukan untuk mengetahui kelayakan dan penerimaan dari sistem yang telah dibangun. Pengujian sistem dibagi menjadi 2 bagian yaitu pengujian fungsionalitas sistem dan pengujian usability atau kegunaan dan kemudahan penggunaan sistem. Pengujian functionality dilakukan untuk mengetahui kesesuaian dan keberhasilan sistem melakukan fungsi-fungsi yang sesuai dengan kebutuhan penggunaan sistem. Pengujian functionality dilakukan dengan metode pengisian angket oleh bidan maupun dokter spesialis kandungan yang sebelumnya telah melakukan percobaan penggunaan sistem. Hasil pengujian functionality menunjukkan bahwa sistem sudah dapat menjalankan $100 \%$ fungsi dengan benar.

Pengujian usability dilakukan untuk mengetahui penerimaan user tehadap sistem yang dibangun. Dalam pengujian usability, user mengisi angket dengan instrumen yang disusun oleh J.R Lewis. Instrumen dan hasil pengisian angket ditunjukkan pada Tabel 1 .

Tabel 1. Hasil Pengujian Usability

\begin{tabular}{|c|c|c|}
\hline No & Pernyataan & Nilai \\
\hline 1 & Secara umum saya puas dengan kemudahan penggunaan sistem & 19 \\
\hline 2 & Cara penggunaan sistem ini mudah & 18 \\
\hline 3 & Saya dapat menyelesaikan pekerjaan saya dengan efektif menggunakan sistem ini. & 18 \\
\hline 4 & Saya dapat dengan cepat menyelesaikan pekerjaan saya menggunakan sistem ini. & 17 \\
\hline 5 & Saya dapat menyelesaikan pekerjaan saya dengan efisien menggunakan sistem ini & 18 \\
\hline 6 & Saya merasa nyaman menggunakan sistem ini. & 17 \\
\hline 7 & Sistem ini mudah dipelajari. & 19 \\
\hline 8 & Saya yakin saya bisa lebih produktif dengan menggunakan sistem ini. & 17 \\
\hline 9 & $\begin{array}{l}\text { Sistem menampilkan pesan kesalahan secara jelas menyertakan solusi } \\
\text { menyelesaikan permasalahan. }\end{array}$ & 16 \\
\hline 10 & $\begin{array}{l}\text { Saya dapat memperbaiki kesalahan dalam menggunakan sistem dengan mudah dan } \\
\text { cepat. }\end{array}$ & 18 \\
\hline 11 & $\begin{array}{l}\text { Informasi tambahan (bantuan, petunjuk pengisian form) disediakan sistem dengan } \\
\text { jelas. }\end{array}$ & 17 \\
\hline 12 & Informasi yang saya butuhkan dapat saya temukan dengan mudah. & 19 \\
\hline 13 & Informasi yang disediakan oleh sistem mudah dimengerti. & 17 \\
\hline 14 & $\begin{array}{l}\text { Informasi yang disediakan oleh sistem sangat efektif dalam membantu saya } \\
\text { menyelesaikan pekerjaan saya. }\end{array}$ & 18 \\
\hline 15 & Tata letak informasi yang ditampilkan sangat jelas. & 18 \\
\hline 16 & Tampilan sistem ini nyaman dilihat dan digunakan. & 18 \\
\hline 17 & Saya menyukai tampilan sistem ini. & 18 \\
\hline 18 & Sistem memiliki semua kemampuan dan fungsi yang saya harapkan. & 20 \\
\hline 19 & Secara umum saya puas dengan sistem ini. & 19 \\
\hline & Total & 341 \\
\hline
\end{tabular}

Hasil pengujian usability sistem berdasarkan Tabel 1 memiliki nilai $85,46 \%$. Telah diketahui bahwa, hasil pengujian functionality memiliki nilai $100 \%$. Oleh karena itu, apabila di rerata dari dua hasil pengujian tersebut, nilai rata-rata kualitas sistem yaitu $92,73 \%$.

\section{SIMPULAN}

Berdasarkan hasil penelitian dan pengujian yang dilakukan, dapat disimpulkan bahwa penelitian ini telah menghasilkan sistem pendukung keputusan klinis untuk memprediksi kejadian asfiksia neonatorum. 
Sistem yang dibangun memiliki fungsi yang lengkap dan sesuai dengan kebutuhan awal penelitian yaitu menyediakan skor APGAR hasil prediksi berdasarkan aturan dalam Rule Based Reasoning maupun perhitungan dalam Case Based Reasoning. Sistem juga memiliki tingkat penerimaan kemudahan penggunaan yang tinggi, yaitu $85,46 \%$.

Sistem maupun metode dalam memprediksi kejadian asfiksia neonatorum dapat dikembangkan agar sistem yang dibangun kemudian menjadi lebih baik. Peneliti memberikan saran untuk pengembangan sistem selanjutnya untuk menambah jumlah basis kasus untuk memperkaya pengetahuan sistem serta pengembangan atribut yang digunakan dalam case based reasoning seperti hasil pembacaan CTG (Cardiotograph) dan/atau USG (ultrasonography).

\section{DAFTAR PUSTAKA}

Aamodt, Agnar dan Enric Plaza. 1994. CaseBased Reasoning: Foundational Issues, Methodological Variations, and System Approaches. AI Communications. Vol. 7. pp 39-59. Belanda : IOS Press.

Balitbang Depkes. 2008. Riset Kesehatan Dasar 2007. Jakarta : Depkes RI.

Brillianningtyas, Lintang. 2014. Hubungan Kehamilan Lewat Waktu dan Bayi Prematur dengan Kejadian Asfiksia Neonatorum di Ruang Kebidanan RSUD dr. Arief Dadi Tjokrodipo Bandar Lampung Periode Juni 2012 Mei 2013. Bandar Lampung : Fakultas Kedokteran Universitas Lampung.

Gilang; Notoatmodjo, Harsoyo; Rakhmawatie, Maya Dian. 2012. Faktor-Faktor Yang Berhubungan Dengan Kejadian Asfiksia Neonatorum (Studi Di RSUD Tugurejo Semarang).Semarang : Universitas Muhammadiyah Semarang
Herawati, Rika. 2013. Faktor-Faktor yang Menyebabkan Terjadinya Asfiksia Neonatorum pada Bayi Baru Lahir di Rumah Sakit Umum Daerah Kabupaten Rokan Hulu. Jurnal Maternity and Neonatal Vol. 1 No. 2 pp 75 - 85. Riau : Universitas Pasir Pengaraian.

Main, J.; Dillon, T.S.; Shiu, S., 2001, A Tutorial on Case-Based Reasoning : Soft Computing in Case-Based Reasoning (Eds), Sprenger-Verlag, London, pp. 1-28.

Prawirohardjo, Sarwono. 2002. Asuhan Neonatal dan Maternal. Jakarta : EGC.

Turban, Efraim. 2005. Decision Support Systems and Intelligent Systems, edisi Bahasa Indonesia Jilid 1.Yogyakarta : Penerbit Andi.

Utomo, Martono Tri. 2011. Risk Factors for Birth Asphyxia. Folia Medica Indonesiana Vol. 47 No. 4 pp 211 2014. Surabaya : Universitas Airlangga.

von Wangenheim, Christiane Greese. 2000. Case Based Reasoning - A Short Introduction. Brazil :Universidade do Vale do Itajaí.

WHO. 2015. World Health Statistics 2015. Diakses dari http://apps.who.int/iris/bitstream/1066 5/170250/1/9789240694439_eng.pdf

WHO. 2016. World Health Statistics 2016 : Monitoring Health For The SDGs. Diakses dari http://apps.who.int/iris/bitstream/1066 5/206498/1/9789241565264_eng.pdf

Wiknjosastro, Hanifa. 2005. Ilmu Kebidanan. Edisi 3. Jakarta : Yayasan Bina Pustaka Sarwono Prawirohardjo. 